\title{
FORMULATION DEVELOPMENT AND IN-VIVO EVALUATION OF BUCCOADHESIVE TABLETS OF VERAPAMIL HYDROCHLORIDE
}

\author{
Gamal A. El-Gindy
}

Department of Pharmaceutics, Faculty of Pharmacy, Assiut University, Assiut 71526, Egyp.

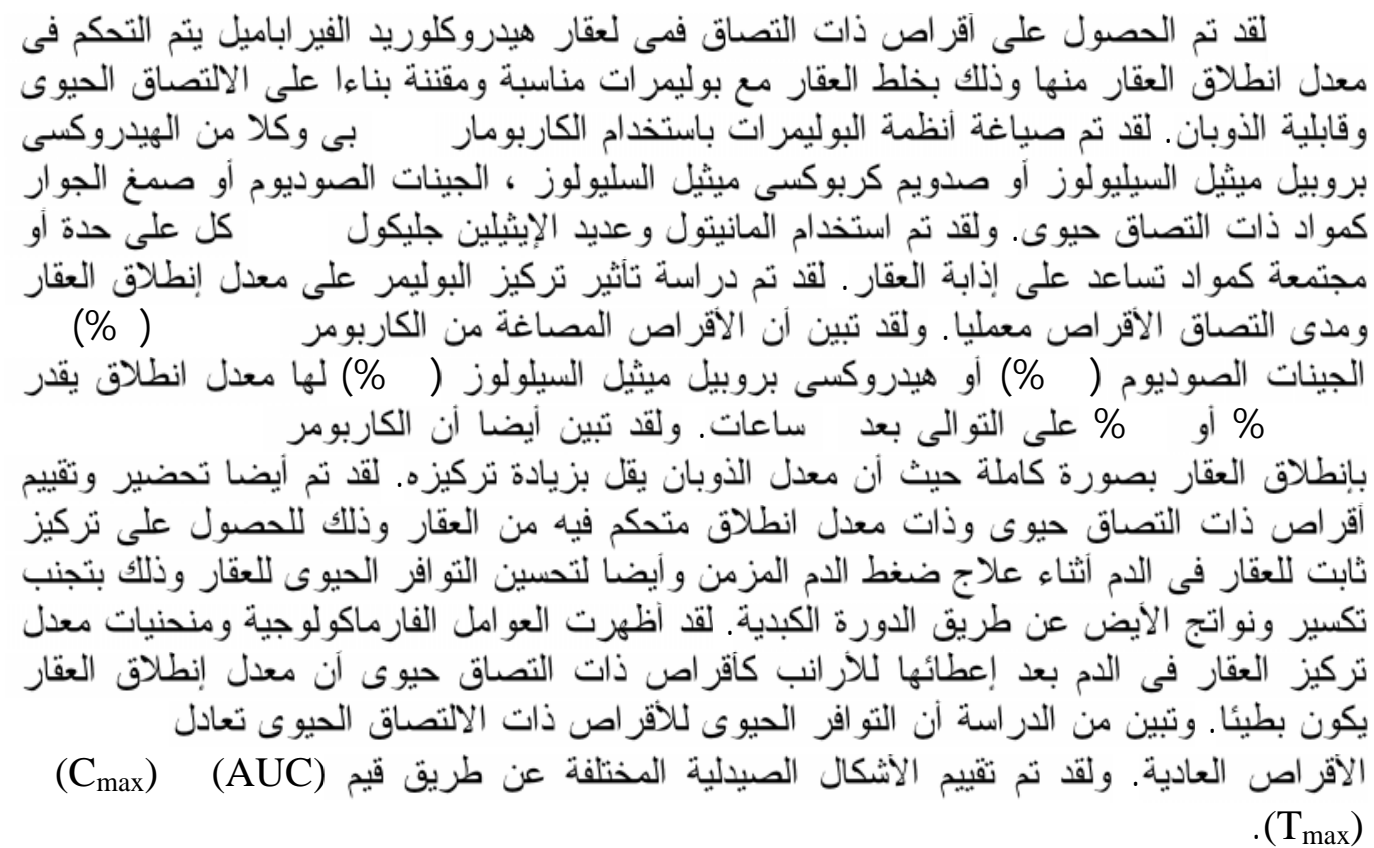

Controlled-released buccoadhesive tablets of verapamil hydrochloride (VH) were obtained by incorporation of VH in suitable carrier systems standardised based on bioadhesion and dissolution. The carrier systems were formulated using carbomor 974P (CP974P) and hydroxypropylmethylcellulose (HPMC) or sodium carboxymethyl cellulose (NaCMC) or sodium alginate or guar gum as the bioadehsives. Mannitol and polyethylene glycol 6000 (PEG6000) were used as solubilizers singly or in combination. The effect of polymer concentration on the release profile and in-vitro bioadhesion of the matrix tablets was studied. Tablet formulations with carbomor $974 \mathrm{P}(5 \%)$, in combination with sodium alginate $(20 \%)$ or HPMC (20\%) showed $98 \%$ or $79 \%$ drug release, respectively after $6 \mathrm{~h}$. The dissolution rate of the drug decreased by increasing CP974P concentration. Controlled-release buccoadhesive tablets containing VH were prepared and evaluated in order to achieve constant plasma concentrations during treatment of chronic hypertension and to improve the bioavailability of VH by the avoidance of hepatic first-pass metabolism. Pharmacological parameters and plasma concentration time curves obtained following buccal administration to rabbits of buccoadhesive tablets showed evidence of sustained release of $\mathrm{VH}$. Bioavailability of $\mathrm{VH}$ was approximately two times that achieved after oral administraion of commercial tablets. The formulations were compared using pharmacokinetic parameters such as $A U C, C_{\max }$ and $T_{\max }$ values.

\section{INTRODUCTION}

Verapamil is a phenylalkylamine calcium antagonist that inhibits the inward movement of calcium into cardiomyocytes and smooth muscle cells. ${ }^{1}$ It is used in the treatment of supraventicular arrhythmias, angina and hypertension. ${ }^{1,2}$ Over $90 \%$ of verapamil is absorbed following oral administration with peak plasma concentrations occurring between 1 and 2 hours. Verapamil is subjected to a very considerable first-pass metabolism in the liver 
with upto $80 \%$ of the dose eliminated in this way. The bioavailability is therefore $20 \%,{ }^{3}$ and is susceptible to large inter- and intraindividual variation. ${ }^{4}$

Sustained-release oral preparations are available for the treatment of angina and hypertension. ${ }^{5,6} \mathrm{VH}$ acts within $5 \mathrm{~min}$ of intravenous administration and in about 1-2 $\mathrm{h}$. after oral adminsitration. ${ }^{7,8}$ Bioavailability of hepatically metabolized drugs such as steroids can be substantially improved by buccal or sublingual dosing, because when administered by these routes, the drug is not exposed too quickly to the metabolic enzymes of the stomach and the liver during absorption. ${ }^{9-11}$ On contact with the buccal mucosa, the drug permeates across the mucosal tissue to reach the systemic circulation.

The buccal mucosa has an expanse to smooth and relatively immobile surface for placement of dosage forms. The introduction of the concept of bioadhesion in drug delivery now permits precise localisation of dosage forms on the mucosal surface. ${ }^{12}$ Mucoadhesive systems have generally been investigated as plateforms for controlled drug delivery. ${ }^{13,14}$

In this article, an attempt has been made to develop verapamil $\mathrm{HCl}$ buccal adhesive tablets to avoid the gastric degradation and first-pass metabolism in the liver. Verapamil $\mathrm{HCl}$ bioavailability in rabbits from CP974P / sodium alginate buccal adhesive tablets has been compared to the bioavailability of commercial drug tablets and verapamil $\mathrm{HCl}$ I.V injection.

The buccoadhesive formulations were investigated for their physicochemical properties such as bioadhesive forces, interaction between drug and different polymers by IR and DSC and in-vitro release of drug.

\section{MATERIALS AND METHODS}

\section{Materials}

Verapamil hydrochloride, VH (Sigma, USA), Diltiazem $\mathrm{HCl}$ (Sigma Chemical Co., St. Louis MO., USA), carbopol 974P (CP974), hydroxypyropylmethyl cellulose (HPMC) (Morgan Chemical Co., Egypt), sodium carboxymethyl cellulose (NaCMC) (Arabic Laboratory Equipment Co., Egypt), Guar gum
(Sigma Chemical Co., Germany), polyethyleneglycol 6000 (PEG600) (Ubichem Ltd., Germany), mannitol BP80 (El-Gomhouria Co., Egypt) and sodium alginate (The General Chemical, Pharmaceutical Co., Ltd., England) and isoptin tablets and isoptin ampoule (ElArabia Pharmaceutical Co., Egypt). The following chemicals and solvents were of chromatographic grade: Acetonitrile, methanol, $\mathrm{N}$-hexnae (BDH Laboratory Supplies, England) and trifluoroacetic acid (Merck Co., Germany). All other chemicals used were of analytical grade.

\section{Methods \\ Preparation of verapamil $\mathrm{HCl}$ bucco- adhesive tablets}

Verapamil $\mathrm{HCl}(\mathrm{VH})$ buccoadhesive tablets, $13 \mathrm{~mm}$ in diameter and with a hardness of $5-8 \mathrm{~kg}$, were prepared by mixing $40 \mathrm{mg} \mathrm{VH}$ with $160 \mathrm{mg}$ other ingredients, such as bioadhesive polymers and suitable excipients, and triturating in a morter. Tablets $(200 \mathrm{mg})$ were compressed on a Carver® press at a force of 3 tons for $25 \mathrm{~s}$ using 13/32 flat-faced punches. These tablets were stored in a desiccator until further used. Two different polymers, CP974 with either one of the following $\mathrm{HPMC}$ or $\mathrm{NaCMC}$ or sodium alginate or guar gum were used. The various formulations prepared containing different weights of polymers and other excipients are listed in Table 1.

\section{Differential scanning calorimetric (DSC) studies}

The DSC patterns of $\mathrm{VH}$ alone, excipients alone as well as 1:1 (w/w) physical mixtures of the drug and investigated excipients, were recorded using a Shimadzu model DSC-50 at scanning rate of $10^{\circ} / \mathrm{min}$ from $30^{\circ}$ to $350^{\circ}$ under nitrogen gas stream at a flow rate of 40 $\mathrm{ml} / \mathrm{min}$. Samples of $5 \mathrm{mg}$ were accurately weighed and encapsulated into a liquid sample pan.

\section{Infrared absorption spectroscopy (IR)}

The IR spectra were obtained with an IR470 infrared spectrophotometer (Shimadzu, Japan) using $\mathrm{KBr}$ disk method. The disks were made under a pressure equal to $400 \mathrm{~kg} / \mathrm{cm}^{2}$. 
Table 1: Composition of the buccoadhesive tablet formulations.

\begin{tabular}{|c|c|c|c|c|c|c|c|c|c|c|c|c|c|c|c|c|c|c|c|c|c|c|c|c|c|c|c|c|c|}
\hline \multirow{2}{*}{$\begin{array}{l}\text { Ingredients } \\
\text { (mg/tablet) }\end{array}$} & \multicolumn{29}{|c|}{ Formulation code } \\
\hline & $\mathrm{F}_{1}$ & $\mathrm{~F}_{2}$ & $\mathrm{~F}_{3}$ & $\mathrm{~F}_{4}$ & $\mathrm{~F}_{5}$ & $\mathrm{~F}_{6}$ & $\mathrm{~F}_{7}$ & $\mathrm{~F}_{8}$ & $\mathrm{~F}_{9}$ & $\mathrm{~F}_{10}$ & $F_{11}$ & $\mathrm{~F}_{12}$ & $\mathrm{~F}_{13}$ & $\mathrm{~F}_{14}$ & $\mathrm{~F}_{15}$ & $F_{16}$ & $\mathrm{~F}_{17}$ & $\mathrm{~F}_{18}$ & $\mathrm{~F}_{19}$ & $\mathrm{~F}_{20}$ & $\mathrm{~F}_{21}$ & $\mathrm{~F}_{22}$ & $\mathrm{~F}_{23}$ & $\mathrm{~F}_{24}$ & $\mathrm{~F}_{25}$ & $\mathrm{~F}_{26}$ & $\mathrm{~F}_{27}$ & $\mathrm{~F}_{28}$ & $\mathrm{~F}_{29}$ \\
\hline $\begin{array}{l}\text { Verapamil } \\
\mathrm{HCl}(\mathrm{VH})\end{array}$ & 40 & 40 & 40 & 40 & 40 & 40 & 40 & 40 & 40 & 40 & 40 & 40 & 40 & 40 & 40 & 40 & 40 & 40 & 40 & 40 & 40 & 40 & 40 & 40 & 40 & 40 & 40 & 40 & 40 \\
\hline CP974P & 130 & 20 & 40 & 60 & 80 & 10 & 30 & 50 & 70 & 10 & 30 & 50 & 70 & 10 & 20 & 30 & 40 & 10 & 20 & 30 & 40 & 10 & 20 & 30 & 40 & 10 & 20 & 30 & 40 \\
\hline HPMC & - & 110 & 90 & 70 & 50 & 70 & 50 & 30 & 10 & - & - & - & - & 40 & 30 & 20 & 10 & - & - & - & - & - & - & - & - & - & - & - & - \\
\hline SCMC & - & - & - & - & - & - & - & - & - & 70 & 50 & 30 & 10 & - & - & - & - & 40 & 30 & 20 & 10 & - & - & - & - & - & - & - & - \\
\hline $\begin{array}{l}\text { Sod. } \\
\text { alginate }\end{array}$ & - & - & - & - & - & - & - & - & - & - & - & - & - & - & - & - & - & - & - & - & - & 40 & 30 & 20 & 10 & - & - & - & - \\
\hline Guar gum & - & - & - & - & - & - & - & - & - & - & - & - & - & - & - & - & - & - & - & - & - & - & - & - & - & 40 & 30 & 20 & 10 \\
\hline Mannitol & 30 & 30 & 30 & 30 & 30 & 30 & 30 & 30 & 30 & 30 & 30 & 30 & 30 & 30 & 30 & 30 & 30 & 30 & 30 & 30 & 30 & 30 & 30 & 30 & 30 & 30 & 30 & 30 & 30 \\
\hline PEG6000 & - & - & - & - & - & 50 & 50 & 50 & 50 & 50 & 50 & 50 & 50 & 80 & 80 & 80 & 80 & 80 & 80 & 80 & 80 & 80 & 80 & 80 & 80 & 80 & 80 & 80 & 80 \\
\hline
\end{tabular}




\section{In-vitro mucoadhesion study}

To investigate how well the tablets would adhere to the buccal mucosa, mucoadhesion of the tablets was measured using a previously published method ${ }^{15}$ using bovine intestine as a model mucosal membrane. Fresh bovine intestine obtained at slaughter was rapidly frozen to $-20^{\circ}$. Before use a circular piece $(2$ $\mathrm{cm}^{2}$ ) of membrane was cut and brought to room temperature in saline solution, then glued with cyanoacrylate adhesive on the ground surface of a tissue holder made of plexiglas. Similarly, the tablet was glued to another holder of the same size. Thereafter, the mucosal membrane was first blotted with a filter paper and then moistened with $25 \mathrm{ul}$ of phosphate buffer $\mathrm{pH}$ 6.8. The tablet was kept in contact with mucosal membrane for $5 \mathrm{~min}$ after which, water was added to the polypropylene bag through an intravenous infusion set at constant rate of one drop/sec. until the tablet detached from the tissue. The water collected in the bag was measured and expressed as weight (g) required for detachment.

\section{Swelling studies of buccoadhesive tablets}

In this study, three tablets for each formulation were placed in a petri dish containing $50 \mathrm{ml}$ of phosphate buffer $\mathrm{pH} 6.8$ maintained at $37.0^{\circ}$. The tablets were removed at time intervals of $0.5,1,2,3,4,5$ and $6 \mathrm{~h}$. Excess water on the surface of the tablets were carfully absorbed using filter paper, and swollen tablets were weighed and the changes of the volume were measured. The diameter and thickness of the tablets were measured using a micrometer. The volume of each tablet was calculated using the following formula: volume $=\pi \cdot \mathrm{d}^{2}$.t. where $\pi=3.14, \mathrm{~d}$ is the diameter of the tablet and $t$ is the thickness of the tablet.

Normalized swelling values were calculated from either normalized swelling volume or normalized swelling weight. ${ }^{16}$

\section{In-vitro drug release studies}

The drug release from the buccal tablets was performed using USP XXIII apparatus 2 (Paddle method) using phosphate buffer (250 $\mathrm{ml}, \mathrm{pH}$ 6.8) as dissolution medium, which was maintained at $37^{\circ}$ and stirred at $50 \mathrm{rpm}$. Each tablet was fixed at a glass slide so that the drug could be released only from the upper surface. Aliquots (5 ml each) were withdrawn after 5 , $15,30,45,60,90,120,150,180,240,360 \mathrm{~min}$ with aid of pipette, the drug content was determined spectrophotometrically at $\lambda_{\max }$ $230 \mathrm{~nm}$.

\section{In-vivo evaluation of buccal tablets}

Six healthy albino rabbits weighing 1.8-2 $\mathrm{kg}$ were used as experimental animals in this study. The rabbits were fasted overnight before the administration of the dosage forms. During all experiments, water ad libitum was available and load given $6 \mathrm{~h}$ after the dose was administered. There was a washout period of 1week prior to in-vivo evaluation of the next formulation.

\section{Intravenous dosing}

Intravenous dosing $(0.625 \mathrm{mg} / \mathrm{kg}$ body weight) was performed using isoptin ampoule $(2.5 \mathrm{mg} / \mathrm{ml})$ (N.B. The dose decreased in this case to prevent cardiac arrest of rabbit which may lead to death).

\section{Buccal dosing}

For buccal dosing, the rabbits were first anesthetized with an urethane and maintained on urethane for $2 \mathrm{~h}$ to allow adhesion of the tablets to the buccal mucosa. Tablets containing $40 \mathrm{mg} \mathrm{VH}\left(\mathrm{F}_{22}\right.$ from Table 1) were cut in five. Each fifth was attached to the buccal mucosa of rabbit by pressing it for 30 sec. Blood samples $(2 \mathrm{ml})$ were withdrawn just before dosing (blank plasma), and at 5, 15, 30, $60,90,120,150,180,240,300,360,420$ and $480 \mathrm{~min}$ from the middle ear vein using a 26gauge needle and syringe and were collected in heparinized vials and stored at $-20^{\circ}$ until assayed. Plasma was obtained via centrifugation and stored at $-10^{\circ}$ until assayed by HPLC as described below.

\section{Oral dosing}

Each rabbit was dosed with commercially available $\mathrm{VH}$ tablet after grinding it and making an aqueous suspension. $3 \mathrm{mg} / \mathrm{kg} \mathrm{VH}$ from the previously prepared suspension were administered orally to rabbits through an intragastric tube, and blood samples were collected and stored as above. 


\section{Assay of verapamil $\mathrm{HCl}$ in plasma}

The analytical method of Watson and Kapur $^{17}$ with some modifications was used to determine verapamil $\mathrm{HCl}$ in plasma as follows: To $500 \mu \mathrm{l}$ plasma, (containing $0.02 \mu \mathrm{g}$ of diltiazem $\mathrm{HCl}$ as an internal standard), $5 \mathrm{ml}$ of n-hexane were added and vortex mixed. The samples were alkalinized with $0.1 \mathrm{ml}$ sodium hydroxide ( $2 \mathrm{M})$, then centrifuged at $3000 \mathrm{rpm}$ for $15 \mathrm{~min}$. The organic layer was transferred to a conical tube and $100 \mu \mathrm{l}$ of mobile phase consisting of acetonitrile / $0.1 \mathrm{M}$ phosphate buffer (40:60) was added. The contents were mixed via vortex for 2 min and centrifuged at $3000 \mathrm{rpm}$ for $15 \mathrm{~min}$. Aliquots of $20 \mu \mathrm{l}$ of aqueous layer were injected onto a C18 column (Lichrosorb C18 RP-column 250x4.6 mm L.D). A flow rate of $1 \mathrm{ml} / \mathrm{min}$ (Knauer-Ministar K500 pump) was used for the mobile phase consisting of $0.1 \mathrm{M} \mathrm{pH} 3$ phosphate buffer / acetonitrile (60:40 parts). $\mathrm{VH}$ and diltiazem (the internal standard) were detected at a wavelength of $230 \mathrm{~nm}$, using a UV detecter (Knauer UV-Vis detector K2500 spectrophotometer). Chromatograms were recorded and analyzed using Shimdazu Chromatopac C-R6A integrator Inc. Osaka, Japan. Standard curves were developed in plasma for the $\mathrm{VH}$ within a range of 100 to $2000 \mathrm{ng} / \mathrm{ml}$. The peak area was plotted as a function of VH concentration. The linearity of the method $(r>0.999)$ was determined to show a directly proportional relationship between the peak response and the concentration of VH. All experiments were run as triplicates and the mean values $\pm \mathrm{SD}$ were taken.

\section{Pharmacokinetic analysis}

Parameters including AUC, $\mathrm{C}_{\max }$ and time to reach maximum plasma concentration $\mathrm{T}_{\max }$ were estimated from the plasma concentrationtime profiles. The area under the plasma concentration-time curve (AUC) from $\mathrm{t}=0 \mathrm{~h}$ to the time of the last blood sample $(\mathrm{t}=8 \mathrm{~h})$ was determined by the linear trapezoidal rule. The AUC values obtained for the various formulations were normalized to $3 \mathrm{mg} / \mathrm{kg}$ (I.V. dose) of rabbit weight using the following formula described by Jain et al. ${ }^{18}$

$$
\text { NormalizedAUC }=\frac{\text { AUCx rabbit } \mathrm{wt} .(\mathrm{kg}) \times 3}{\text { Actualdose }(\mathrm{mg})} . .
$$

The normalization of the data was done because the I.V formulation contained different dose of verapamil $\mathrm{HCl}$. The absolute and relative bioavailabilities were evaluated using the following equations:

Absolute BA $(\mathrm{F})=\frac{\mathrm{AUC}^{\mathrm{b}}}{\mathrm{AUC}^{\mathrm{I.V}}} \times \frac{\text { Dose }^{\mathrm{IIV}}}{\text { Dose }^{\mathrm{b}}} \times 100 \ldots$

Relative $\mathrm{BA}=\frac{\mathrm{AUC}^{\mathrm{b}}}{\mathrm{AUC}^{\mathrm{VH}}} \cdots \ldots \ldots \ldots \ldots$

where AUC $=$ area under the curve, $\mathrm{b}=$ buccal, $\mathrm{I} . \mathrm{V}=$ intravenous, and $\mathrm{VH}=$ verapamil $\mathrm{HCl}$.

Statistical analysis were performed using a Student's $\mathrm{t}$ test with $\mathrm{p}<0.05$ as the minimal level of significance.

\section{Pharmacological effect of VH Induction of experimental hypertension to rabbits}

Vasopressin was diluted with normal saline and given by I.V route in the marginal ear vein of the rabbit in a dose of 0.2 unit $/ \mathrm{kg}$ daily. The ear must be well cleaned before and after the injection by ethyl alcohol.

\section{Measurement of the mean blood pressure of induced hypertensive rabbits}

The hypertensive rabbits were subdivided into three groups, three animals each. The rabbits were first anaesthetized with an intraperitoneal injection of urethane solution $(25 \%)$ in a dose of $6.4 \mathrm{ml} / \mathrm{kg}$. After shaving the neck, the trachea was canulated with a polyethylene tube. The animals were ventillated with room air. ${ }^{19}$ Then the animals were prepared for I.V. injection of heparinized saline $(1000 \mathrm{U} / \mathrm{kg})$ through a canula placed in the right jugular vein. The rabbits of the first group were given VH $3 \mathrm{mg} / \mathrm{kg}$ (Isoptin 80, Knoll) orally by using a stomach tube. The animals of the second group were given $\mathrm{VH}$ $0.625 \mathrm{mg} / \mathrm{kg}$ intravenously (Isoptin ampoule, Knoll $5 \mathrm{mg} / 2 \mathrm{ml}$ ). The third group was given $\mathrm{VH}$ buccoadhesive tablet $3 \mathrm{mg} / \mathrm{kg}$ of the selected formula $\left(\mathrm{F}_{22}\right)$ by attaching the part of tablet to the buccal mucosa (under pouch) of rabbits by pressing it for $30 \mathrm{sec}$. During the study, the rabbit breathed normally and body temperature was maintained at $37^{\circ}$ with the use of a heating pad. ${ }^{20}$ 
The mean atrial blood pressure and pulse rate were measured from the canulated left common carotid artery which was canulated by a special canula attached to blood pressure transductor (BLP world precision instruments, INC, (WP1) USA) and an amplifier of four channels physiograph (TBN4-A, 120/240 VAC, 50/60 Hz, $20 \mathrm{VA}$, for four-channels world precision instruments, INC, (WP1) USA) which was connected to two channel recorder (Kipp and Zonen Company, PD112, Holland). The blood pressure and pulse rate were measured at suitable time intervals.

\section{The ECG pictures of different VH formulations used}

ECG is the body surface manifistation of the depolarization and repolarization waves of the heart. Cardisuny needles (Electrocardiograph, model 5010 Lead 2 AC 220 V, 50/60 Hz, 15 AV, Fukuda M.C., Kogyo Co., Ltd, Tokyo, Japan) were put subcutaneously. ECG pictures and pulse rate were measured at suitable time intervals.

\section{RESULTS AND DISCUSSION}

Buccoadhesive polymer CP974P grade was selected as it is a safer analogue of CP934P polymerized in ethyl acetate. Studies involving CP974P have indicated that it has a mild irritation effect to the buccal mucosa at higher concentration. ${ }^{21}$ The prepared buccoadhesive tablets of $\mathrm{VH}$ were evaluated for physical characteristics. The results showed that all of the buccoadhesive tablets were acceptable in regard to $\mathrm{VH}$ content $(100 \pm 4 \%)$, weight variation (Bp 1998) and friability. Tablets with crushing strengths between 1.9$10.3 \mathrm{~kg}$ were obtained with carbopol 974 and other polymers, hardness decreased with increasing the amounts of HPMC, SCMC, sodium alginate and guar gum. The differences in the tablet strengths were reported not to affect the release of the drug from hydrophilic matrices. ${ }^{22}$ The drug was released by diffusion through the gel layer and/or erosion of this layer and is therefore independant of the dry state of the tablet. ${ }^{22}$

\section{IR spectroscopy}

IR spectra of the drug, neat polymer and drug/polymers physical mixtures are presented in Figure 1. The characteristic IR absorption peaks of $\mathrm{VH}$ (curve a) showed the $\mathrm{C}-\mathrm{H}$ stretching vibrations of the methoxy group at $2840 \mathrm{~cm}^{-1}$. The N-H stretching of the protonated amine group is observed in the range $2800-2300 \mathrm{~cm}^{-1}$, and a strong absorption band due to $\mathrm{C}-\mathrm{O}$ stretching of the aromatic ester group appeared at $1262 \mathrm{~cm}^{-1}$. IR spectra of the $\mathrm{VH} /$ polymers (curves c, e, g, i, k, m and o) showed a prominent peak for $\mathrm{VH}$ at 1517 $\mathrm{cm}^{-1}$, which is due to benzene rings. This indicates that $\mathrm{VH}$ is not involved in any chemical reactions with any of polymers.
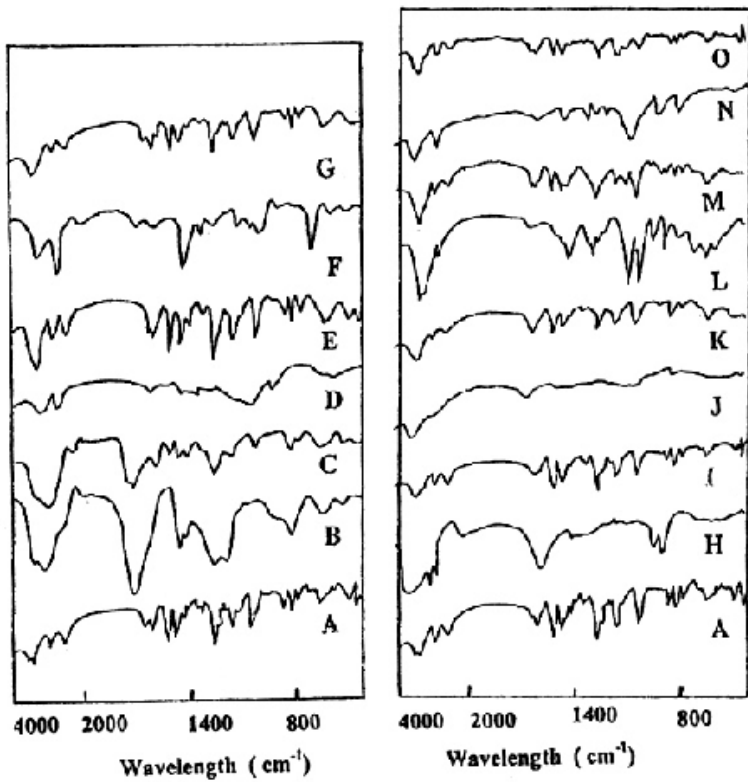

Fig. 1: IR spectra of verapamil $\mathrm{HCl}(\mathrm{A})$; carbopol 974P (B); physical mixture (1:1) of VH and CP974P (C); HPMC (D); physical mixture (1:1) of VH and HPMC (E); NaCMC (F) and physical mixture (1:1) of $\mathrm{VH}$ and $\operatorname{NaCMC}(\mathrm{G})$; sodium alginate $(\mathrm{H})$; physical mixture (1:1) of $\mathrm{VH}$ and sodium alginate (I); guar gum (J); physical mixture of $\mathrm{VH}$ and guar gum (K); mannitol (L); physical mixture of VH and mannitol (M); PEG6000 $(\mathrm{N})$ and physical mixture (1:1) of $\mathrm{VH}$ and PEG6000 (O).

\section{Differential scanning calorimetry (DSC)}

Thermal traces of the samples under study are presented in Figure 2. The endothermic peak of pure $\mathrm{VH}$ appeared at its melting point, $145^{\circ}$ (curve a), which did not changed by the presence of any of the bioadhesive polymers. This was a further confirm of the absence of an interaction between $\mathrm{VH}$ and any of the polymers. 

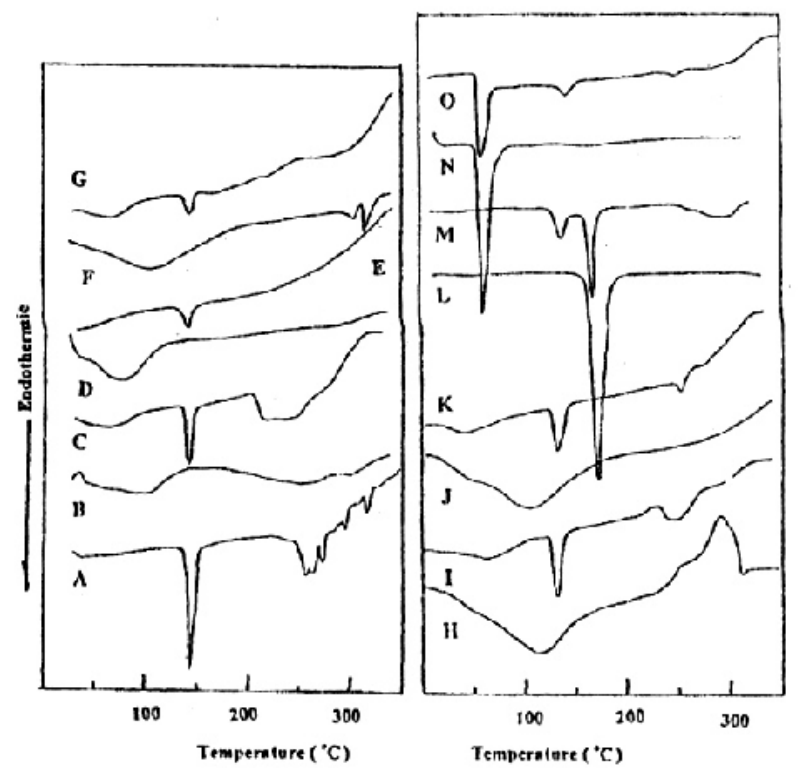

Fig. 2: DSC thermograms of Verapamil (A); CP974P (B); physical mixture (1:1) of VH and CP974P (C); HPMC (D); physical mixture (1:1) of VH and HPMC (E); NaCMC (F); physical mixture (1:1) VH and $\mathrm{NaCMC}(\mathrm{G})$; sodium alginate $(\mathrm{H})$; physical mixture (1:1) of $\mathrm{VH}$ and sodium alginate (I); guar gum (J); physical mixture (1:1) of $\mathrm{VH}$ and guar gum $(\mathrm{K})$; mannitol (L); physical mixture (1:1) of $\mathrm{VH}$ and mannitol (M); PEG6000 (N); physical mixture (1:1) of VH and PEG6000 (O).

\section{Swelling index studies}

The swelling behavior of the tablets is important in regard of bioadhesion and drug release. ${ }^{23}$ The normalized swelling values of the matrices with CP974 and HPMC increased with increasing the amount of the first polymer. Maximum swelling was seen with formulation containing sodium alginate and PC974 (Table $2)$. The values increased with increasing amounts of sodium alginate. The normalized swelling values of tablets were in the order of $\mathrm{F}_{22}>\mathrm{F}_{26}>\mathrm{F}_{25}>\mathrm{F}_{29}>\mathrm{F}_{18}>\mathrm{F}_{17}>\mathrm{F}_{1}>\mathrm{F}_{14}>\mathrm{F}_{21}$. In general, it was observed that the normalized swelling values were found to be increased with increasing the concentration of the second bioadhesive polymer.

\section{In-vitro bioadhesion study}

Bioadhesion force means the force with which tablets bind to buccal mucous membranes. The bioadhesive forces of the tablets were chiefly affected by the nature and ratio of the bioadhesive polymers, since they were different in nature. ${ }^{24-26}$ The highest detachment force was observed with formulation $\mathrm{F}_{1}$ prepared with $65 \%$ CP974 (Table 2). Increasing the content of CP974 resulted in increased detachment forces, which is in compliance with the literature. ${ }^{27}$

Table 2: Normalized swelling values and bioadhesive strength of the buccoadhesive tablet formulations.

\begin{tabular}{||c|c|c|c||}
\hline Code & $\begin{array}{c}\mathrm{W} \pm \mathrm{SD} \\
(\mathrm{g} / \mathrm{g})\end{array}$ & $\begin{array}{c}\mathrm{V} \pm \mathrm{SD} \\
\left(\mathrm{mm}^{3} / \mathrm{mm}^{3}\right)\end{array}$ & $\begin{array}{c}\text { Bioadhesive strength } \\
( \pm \mathrm{SD})(\mathrm{g})\end{array}$ \\
\hline $\mathrm{F}_{1}$ & $2.88 \pm 0.11$ & $2.25 \pm 0.24$ & $53.91 \pm 2.29$ \\
\hline $\mathrm{F}_{14}$ & $2.52 \pm 0.15$ & $2.35 \pm 0.15$ & $23.63 \pm 2.05$ \\
\hline $\mathrm{F}_{17}$ & $3.021 \pm 0.14$ & $3.96 \pm 0.09$ & $43.51 \pm 1.92$ \\
\hline $\mathrm{F}_{18}$ & $3.15 \pm 0.21$ & $3.92 \pm 0.19$ & $26.49 \pm 1.05$ \\
\hline $\mathrm{F}_{21}$ & $2.25 \pm 0.09$ & $2.72 \pm 0.24$ & $48.75 \pm 2.35$ \\
\hline $\mathrm{F}_{22}$ & $6.682 \pm 0.24$ & $6.52 \pm 0.41$ & $38.5 \pm 2.15$ \\
\hline $\mathrm{F}_{25}$ & $3.724 \pm 0.18$ & $4.05 \pm 0.31$ & $41.25 \pm 1.52$ \\
\hline $\mathrm{F}_{26}$ & $4.762 \pm 0.15$ & $4.93 \pm 0.23$ & $20.38 \pm 1.78$ \\
\hline $\mathrm{F}_{29}$ & $3.243 \pm 0.17$ & $3.85 \pm 0.16$ & $38.5 \pm 0.89$ \\
\hline \hline
\end{tabular}

Values are mean of three readings \pm SD.

$\mathrm{W}$ : weight

$\mathrm{V}$ : volume 


\section{In-vitro dissolution of buccal tablets}

The time course of $\mathrm{VH}$ release from various formulations is shown in Figures $3 \mathrm{a}-3 \mathrm{~g}$. The release of VH from buccoadhesive tablets varied according to the type and ratio of the polymer used. Tablets prepared using formulations $\mathrm{F}_{1}$ to $\mathrm{F}_{9}$ did not show any significant differences in their dissolution profiles (Figures $3 \mathrm{a}$ and $3 \mathrm{~b}$ ). However, the rate of $\mathrm{VH}$ release from tablets containing insoluble PC974P was slower than that contained water soluble HPMC, or sodium alginate. On the other hand, the release of $\mathrm{VH}$ decreased with increasing concentration of carbopol 974P. This decrease in the rate of drug release may be attributed to entrappment of the drug in the core of carbopol matrix. On hydration of the surface, a gelatinous layer was formed that consisted of discrete microgels made up of many polymer particles in which the drug is dispersed. When the hydrogel was completely hydrated, it did not dissolve, but osmotic pressure worked to break up the structure, mainly by sloughing off discrete pieces of the hydrogel. The hydrogel remained intact and the drug continuously diffused through the gel layer at a more or less constant rate. It is postulated that as the concentration of the drug becomes high within the gel matrix and its thermodynamic potential increases, the gel layer around the tablet core acts as a ratecontrolling membrane, resulting in a linear release of the drug. ${ }^{28}$ All the formulations evaluated for dissolution showed controlledrelease behavior. Almost $98 \%$ of verapamil $\mathrm{HCl}$ was released at the end of $6 \mathrm{~h}$ in formulation $\mathrm{F}_{22}$.

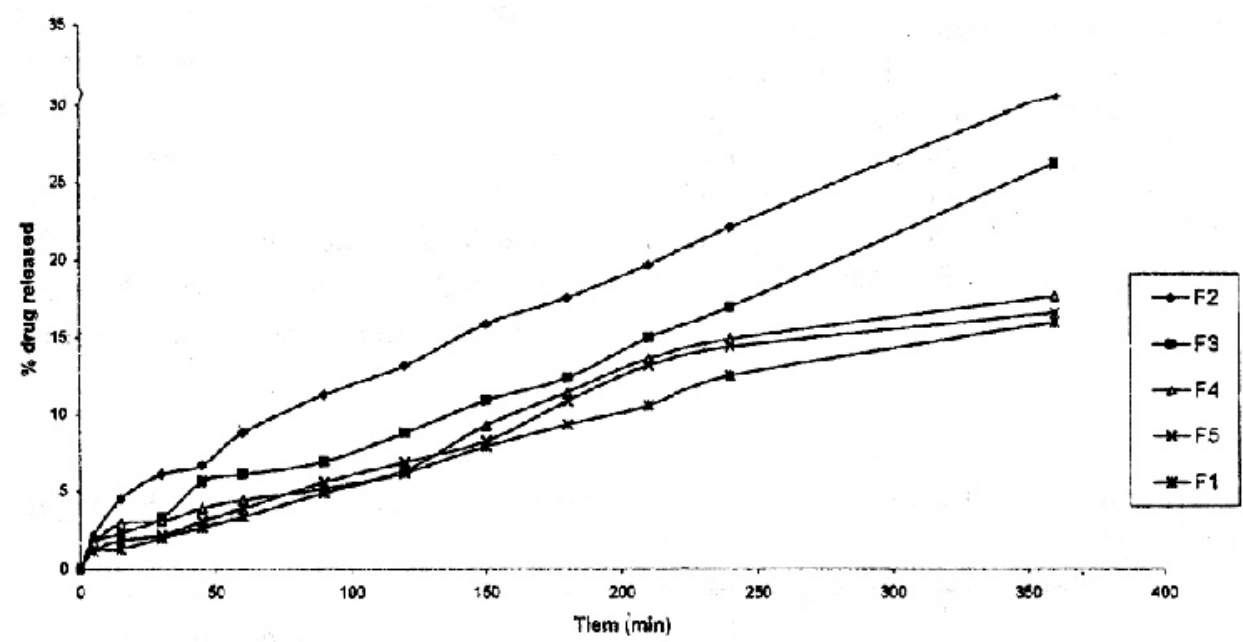

Fig. 3a: In vitro release profiles of verapamil $\mathrm{HCl}$ from formulations $\mathrm{F} 1-\mathrm{F} 5$.

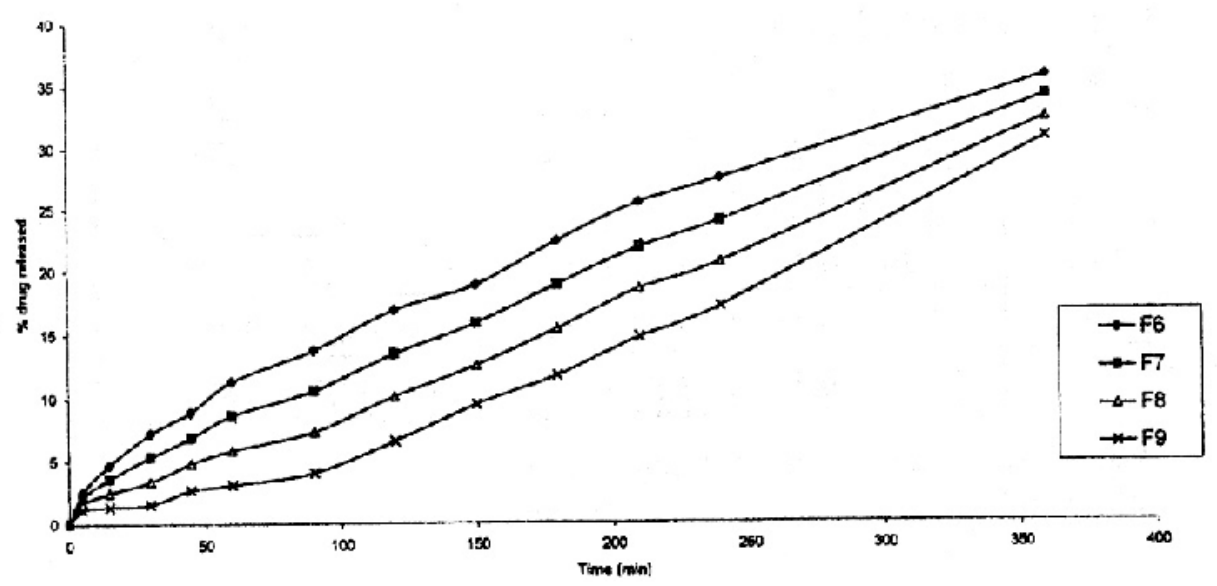

Fig. 3b: In vitro release profiles of verapamil $\mathrm{HCl}$ from formulations F6-F9. 


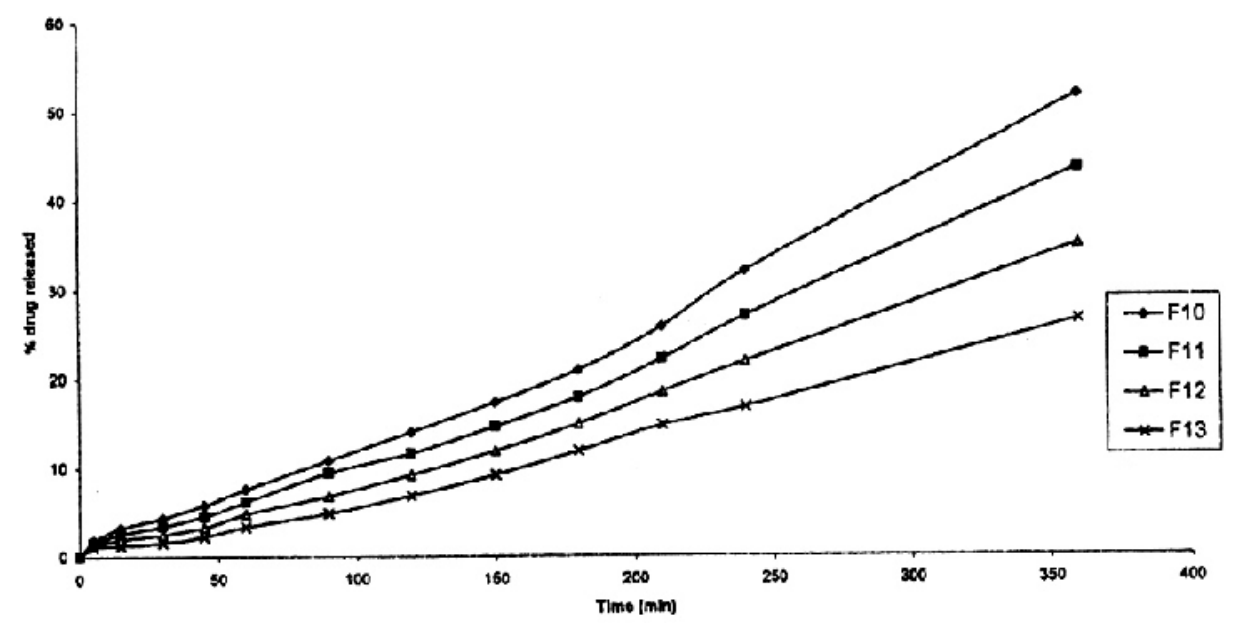

Fig. 3c: In vitro release profiles of verapamil $\mathrm{HCl}$ from formulations F10-F13.

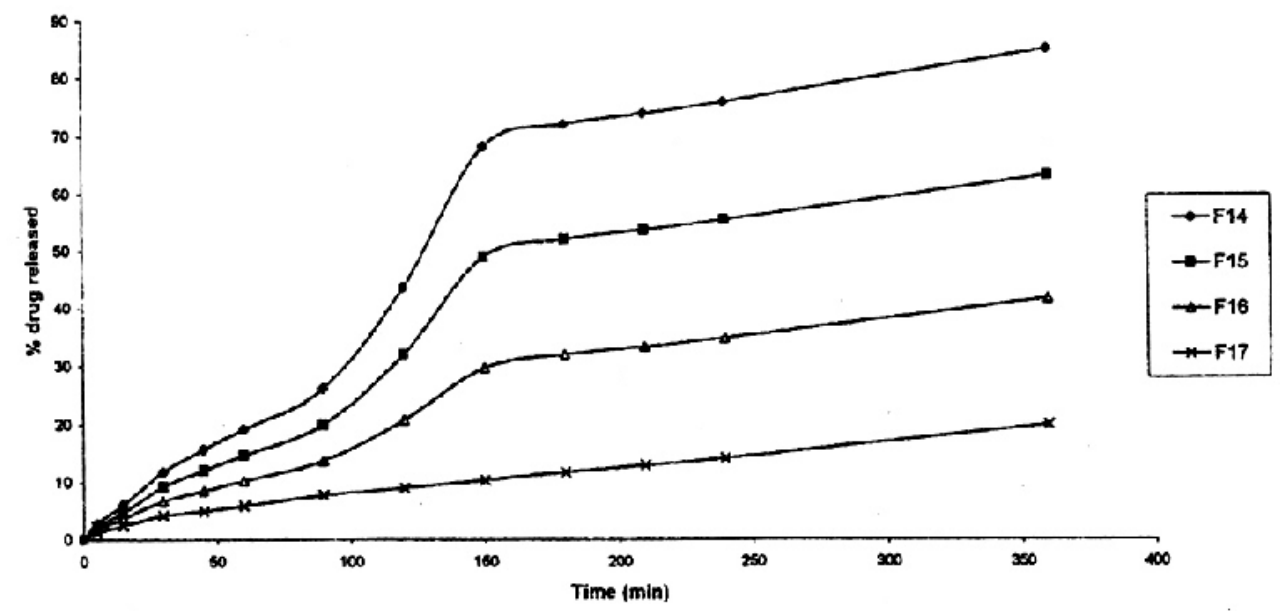

Fig. 3d: In vitro release profiles of verapamil $\mathrm{HCl}$ from formulations F14-F17.

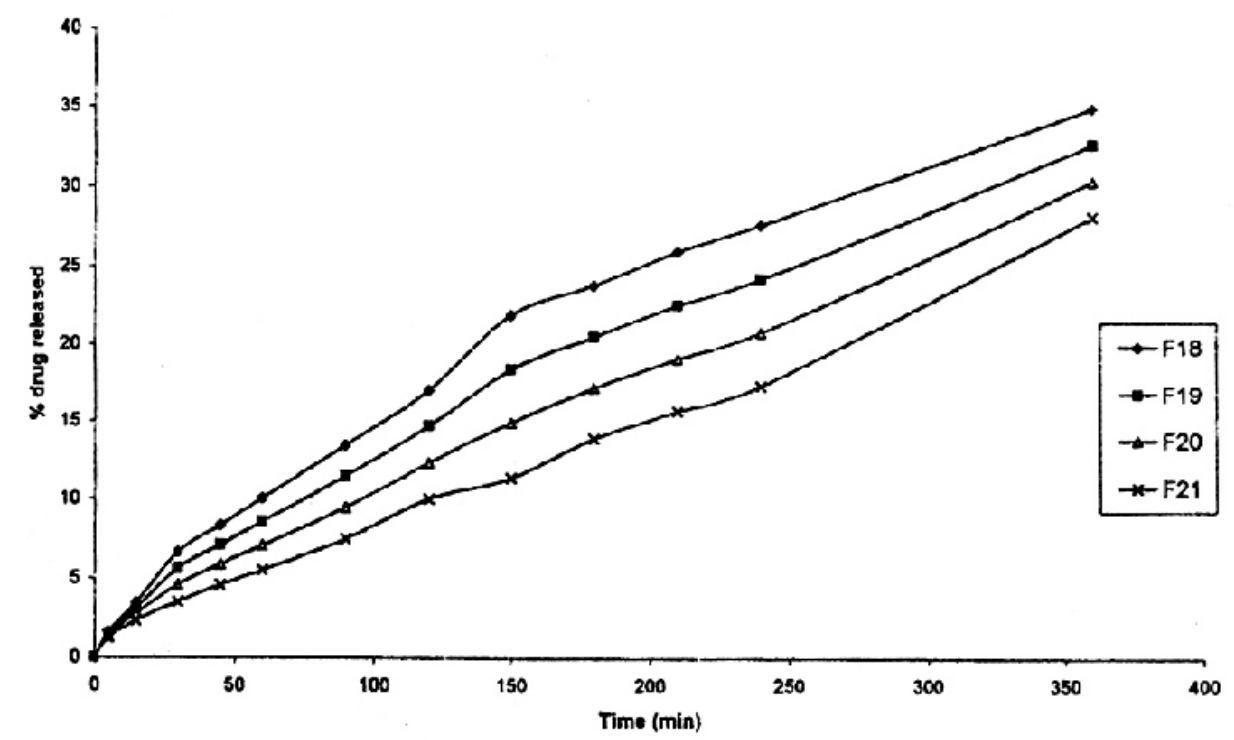

Fig. 3e: In vitro release profiles of verapamil $\mathrm{HCl}$ from formulations F18-F21. 


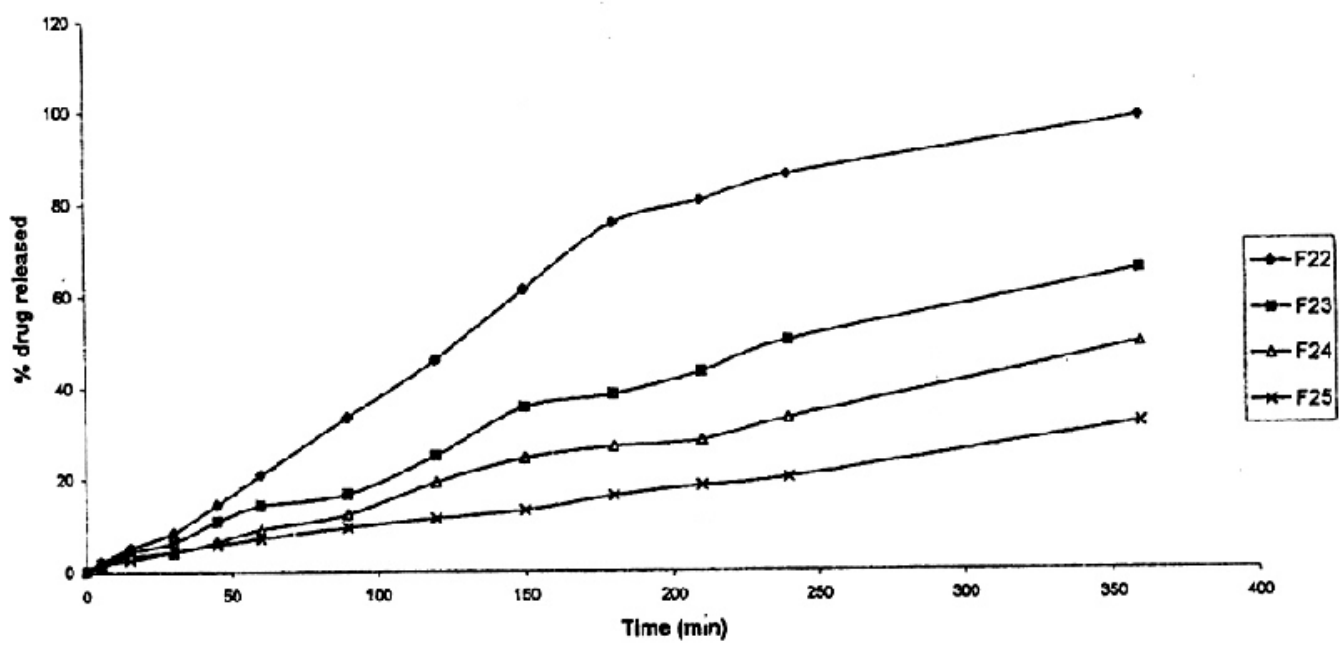

Fig. 3f: In vitro release profiles of verapamil $\mathrm{HCl}$ from formulations F22-F25.

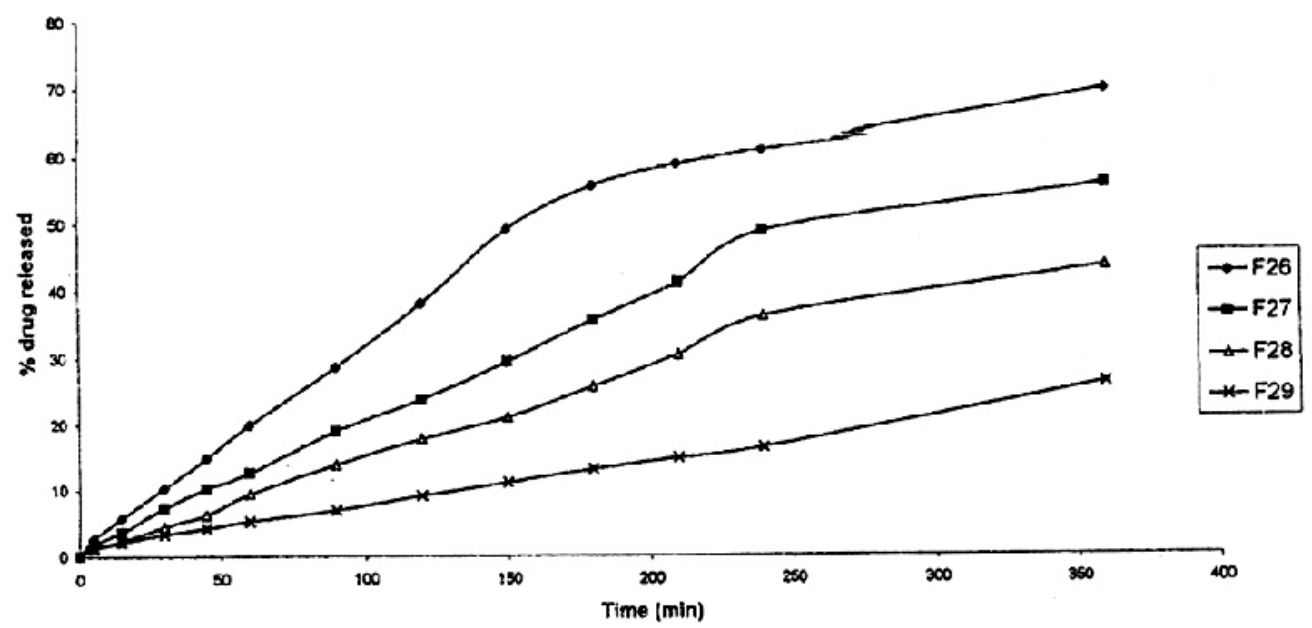

Fig. 3g: In vitro release profiles of verapamil $\mathrm{HCl}$ from formulations F26-F29.

\section{Drug release kinetics}

Drug release rates from the various formulations can be described by eq. 4, to characterize the release mechanism of $\mathrm{VH}$

$$
\frac{\mathrm{M}_{\mathrm{t}}}{\mathrm{M}_{\infty}}=\mathrm{Kt}^{\mathrm{n}}
$$

Where $M_{t} / M_{\infty}$ is the fraction of drug release at time $\mathrm{t}, \mathrm{K}$ is a kinetic constant incorporating structural and geometrical characteristics of tablets, and $\mathrm{n}$ is the diffusional exponent indicative of the release mechanism. ${ }^{29}$ The value of $\mathrm{n}$ is 0.5 for Fickian release, i.e., the release of drug is mainly by diffusion, $>0.5$ and
$<1$ for anomalous or non-Fickian release, i.e., the drug release is by diffusion as well as erosion of polymer and $n=1$, for drug release that follows a zero-order mechanisms. The parameters $\mathrm{K}, \mathrm{n}$ and $\mathrm{r}^{2}$ (correlation coefficient) are listed in Table 3. All the $\mathrm{n}$ values ranged between 0.575 and 0.982 indicating that the drug release is non-Fickian, i.e., the mechanism of drug release is due to polymer erosion as well as diffusion.

Based on the drug release and mucoadhesion studies, formula $\mathrm{F}_{22}$ was chosen as buccoadhesive tablet used consequently in bioavailability studies. 
Table 3: Kinetic constant (K), diffusional exponent (n) and correlation coefficient $\left(\mathrm{r}^{2}\right)$ following linear regression of $\log \left(\mathrm{M}_{\mathrm{t}} / \mathrm{M}_{\infty}\right)$ versus $\log (\mathrm{t})$ of various bioadhesive tablets.

\begin{tabular}{|c|c|c|c|}
\hline Batch no. & $\mathrm{N}$ & $\mathrm{K}$ & $\mathrm{R}^{2}$ \\
\hline F1 & 0.696 & 0.00232 & 0.973 \\
\hline F2 & 0.607 & 0.00765 & 0.995 \\
\hline F3 & 0.650 & 0.00441 & 0.982 \\
\hline F4 & 0.575 & 0.00516 & 0.963 \\
\hline F5 & 0.692 & 0.0027 & 0.979 \\
\hline F6 & 0.623 & 0.00873 & 0.998 \\
\hline F7 & 0.657 & 0.00614 & 0.994 \\
\hline F8 & 0.716 & 0.00361 & 0.980 \\
\hline F9 & 0.821 & 0.0015 & 0.945 \\
\hline F10 & 0.785 & 0.00363 & 0.981 \\
\hline F11 & 0.794 & 0.00291 & 0.977 \\
\hline F12 & 0.805 & 0.00218 & 0.964 \\
\hline F13 & 0.825 & 0.00146 & 0.955 \\
\hline F14 & 0.880 & 0.00608 & 0.988 \\
\hline F15 & 0.851 & 0.0051 & 0.990 \\
\hline F16 & 0.789 & 0.0046 & 0.993 \\
\hline F17 & 0.632 & 0.0045 & 0.998 \\
\hline F18 & 0.737 & 0.0049 & 0.998 \\
\hline F19 & 0.731 & 0.0044 & 0.999 \\
\hline F20 & 0.723 & 0.0039 & 0.998 \\
\hline F21 & 0.717 & 0.0033 & 0.992 \\
\hline F22 & 0.982 & 0.0038 & 0.992 \\
\hline F23 & 0.870 & 0.0039 & 0.995 \\
\hline F24 & 0.836 & 0.0032 & 0.990 \\
\hline F25 & 0.731 & 0.0036 & 0.997 \\
\hline F26 & 0.829 & 0.0066 & 0.994 \\
\hline F27 & 0.847 & 0.0041 & 0.997 \\
\hline F28 & 0.873 & 0.0026 & 0.993 \\
\hline F29 & 0.727 & 0.0029 & 0.993 \\
\hline & & & \\
\hline
\end{tabular}

\section{In-vivo studies}

Under the condition of analytical procedure previously mentioned, the retention times of $\mathrm{VH}$ and diltiazem $\mathrm{HCl}$ were found to be 10.167 and $6.35 \mathrm{~min}$, respectively (Figure 4), which are appropriate times for HPLC analysis. It can be seen in Figure 4 that the peak of $\mathrm{VH}$ is well resoluted from that of diltiazem $\mathrm{HCl}$.

The mean plasma levels profiles versus time of $\mathrm{VH}$ obtained after buccal dosing of formulation $\mathrm{F}_{22}$ is shown in Figure 5. For comparative purpose, the plasma concentration-time profile after oral and intravenous administration of $\mathrm{VH}$ is also shown. Absorption of $\mathrm{VH}$ from buccoadhesive tablets was much slower and extended over a longer period of time compared with oral and intravenous $\mathrm{VH}$. The plasma concentration curves for buccoadhesive tablet showed evidence of a more sustained release of $\mathrm{VH}$.

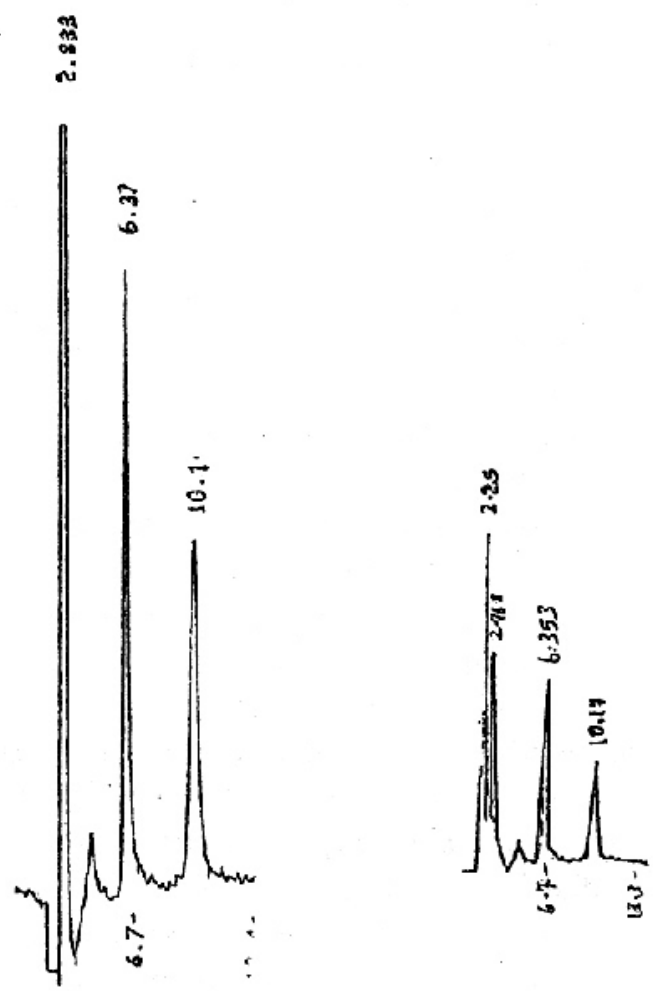

Fig. 4: HPLC chromatograms of $\mathrm{VH}$ and diltiazem $\mathrm{HCl}$ in water (A) and in plasma (B).

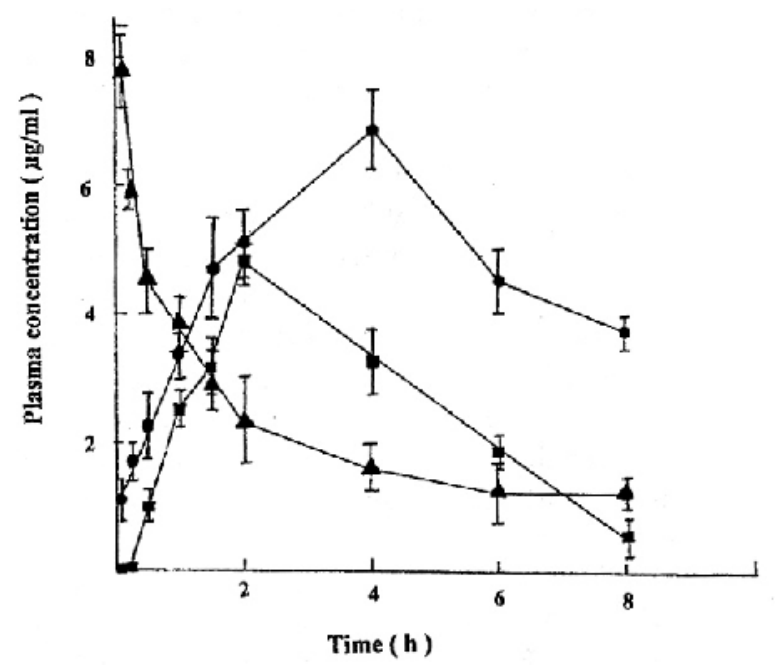

Fig. 5: Mean plasma concenrations of verapamil $\mathrm{HCl}$ after drug administration via oral route (ם), buccal route $(\boldsymbol{)})$ and intravenous route (A) to rabbits at dose level of $3 \mathrm{mg} / \mathrm{kg}$ for oral and buccal tablets and $0.625 \mathrm{mg} / \mathrm{kg}$ for intravenous injection. 
Table 4: Bioavailability parameters of verapamil $\mathrm{HCl}$ from different formulations $(\mathrm{n}=3 \pm \mathrm{SD})$.

\begin{tabular}{||c|c|c|c|c|c||}
\hline \hline Formulations & $\begin{array}{c}\mathrm{C}_{\max } \\
(\mu \mathrm{g} / \mathrm{ml})\end{array}$ & $\mathrm{T}_{\max }(\mathrm{h})$ & $\begin{array}{c}\mathrm{AUC}_{(0-8)} \\
(\mu \mathrm{g} . \mathrm{h} / \mathrm{ml})\end{array}$ & $\begin{array}{c}\text { Absolute BA } \\
(\mathrm{F} \%)\end{array}$ & Relative BA \\
\hline Intravenous & - & - & $81.36 \pm 0.96$ & 100 & - \\
\hline Oral & $4.82 \pm$ & $2.0 \pm 0.30$ & $20.21 \pm 0.763$ & 24.81 & - \\
\hline $\begin{array}{c}\text { Buccoadhesive } \\
\text { tablet }\left(\mathrm{F}_{22}\right)\end{array}$ & $6.85 \pm$ & $4.0 \pm 0.00$ & $38.11 \pm 0.840$ & 46.95 & 1.89 \\
\hline
\end{tabular}

The pharmacokinetic parameters derived from these plasma concentration-time curves are given in Table 4 . The bioavailability of $\mathrm{VH}$ calculated from the ratio AUC [(oral or buccal / i.v.) $x$ 100] was $46.95 \%$ for buccoadhesive tablet, which compares favourably with a value $24.81 \%$ calculated for oral bioavailability. These observations clearly indicate that the bioavailability of $\mathrm{VH}$ from buccoadhesive tablet is significantly improved (approximately two fold) over the bioavailability observed after oral administration of drug solution. This is attributed to avoidance of the first-pass metabolism through the buccal route. Further delayed $\mathrm{T}_{\max }$ and $\mathrm{C}_{\max }$ values from the buccoadhesive tablets compared to drug solution and maintainance of higher blood levels until the last sample from the buccoadhesive tablet than for the drug solution clearly indicate that the buccoadhesive dosage form not only improved the bioavailability of the drug $\mathrm{VH}$, but also gave prolonged and controlled blood level profiles of $\mathrm{VH}$.

\section{Pharmacological activity \\ Effect of VH in different dosage forms on mean blood pressure of induced hyper- tensive rabbits}

Table 5 summarizes the effect of $\mathrm{VH}$ from the tested preparations on the blood pressure of induced hypertensive rabbits. Data in Table 5 showed that, the reduction in blood pressure after drug suspension administered orally, began after $30 \mathrm{~min}(140 \pm 7.5 \mathrm{mmHg})$ and continued for $4 \mathrm{~h}$. A maximal antihypertensive effect was reached at around $2 \mathrm{hr}(103 \pm 6.3$ $\mathrm{mmHg}$ ). Results of commercially available intravenous $\mathrm{VH}(0.625 \mathrm{mg} / \mathrm{kg})$ revealed that, the antihypertensive effects on blood pressure of hypertensive rabbits occurred just after administration and reached a maximum effect after $15 \mathrm{~min}(69 \pm 4.3 \mathrm{mmHg})$. This effect in blood pressure remained for $5 \mathrm{~h}$. In case of buccoadhesive tablet $(3 \mathrm{mg} / \mathrm{kg}$ ), the results show that, the antihypertensive effect on blood pressure of hypertensive rabbits was significantly observed after $15 \mathrm{~min}(120 \pm 5.4$ $\mathrm{mmHg}$ ) and reached its maximum effect at around $4 \mathrm{~h}(63 \pm 4.8)$ and continued until last sample.

Table 5: Effect of oral, buccal and intravenous verapamil $\mathrm{HCl}$ on the mean blood pressure $(\mathrm{mmHg})$ of induced hypertensive rabbits.

\begin{tabular}{||c|c|c|c||}
\hline \hline \multirow{2}{*}{$\begin{array}{c}\text { Time } \\
\text { (min) }\end{array}$} & \multicolumn{3}{|c|}{ Mean blood pressure $(\mathrm{mmHg})$} \\
\cline { 2 - 4 } & Oral VH & $\begin{array}{c}\text { Buccal } \\
\text { VH }\end{array}$ & I.V. VH \\
\hline 0 & $150 \pm 5.5$ & $160 \pm 8.5$ & $50 \pm 6.3$ \\
5 & $150 \pm 6.7$ & $151 \pm 4.8$ & $74 \pm 4.8$ \\
15 & $150 \pm 5.4$ & $120 \pm 5.4$ & $69 \pm 4.3$ \\
30 & $140 \pm 7.5$ & $110 \pm 6.2$ & $73 \pm 5.0$ \\
45 & $131 \pm 5.2$ & $102 \pm 4.6$ & $76 \pm 6.2$ \\
60 & $120 \pm 4.8$ & $94 \pm 5.3$ & $82 \pm 5.2$ \\
90 & $113 \pm 5.6$ & $88 \pm 7.2$ & $89 \pm 5.6$ \\
120 & $103 \pm 6.3$ & $75 \pm 6.7$ & $92 \pm 6.5$ \\
150 & $110 \pm 4.3$ & $70 \pm 4.8$ & $97 \pm 4.9$ \\
180 & $120 \pm 3.7$ & $69 \pm 5.7$ & $115 \pm 5.6$ \\
240 & $138 \pm 5.6$ & $63 \pm 4.8$ & $128 \pm 3.9$ \\
300 & $146 \pm 61.5$ & $75 \pm 6.4$ & $139 \pm 5.6$ \\
360 & $150 \pm 8.8$ & $84 \pm 4.5$ & $149 \pm 5.3$ \\
420 & $150 \pm 5.8$ & $90 \pm 6.5$ & $150 \pm 6.6$ \\
480 & $149 \pm 6.7$ & $125 \pm 4.9$ & $149 \pm 7.3$ \\
\hline
\end{tabular}

Normal systolic blood pressure of rabbits is 90 $\mathrm{mmHg}$.

\section{Relationship between plasma concentration of $\mathrm{VH}$ and the pharmacological response after buccal administration to rabbits at dose of $3 \mathrm{mg} / \mathrm{kg}$}

Table 6 shows the effect of plasma concentration of $\mathrm{VH}$ on the pharmacological response (blood pressure and heart rate), where 
VH has a direct relationship between plasma concentration and pharmacological response. ${ }^{30}$

Table 6: Effect of $\mathrm{VH}$ plasma concentration on the pharmacological response after buccaladhesive tablet administration to rabbits.

\begin{tabular}{||c|c|c|c||}
\hline $\begin{array}{c}\text { Time } \\
(\mathrm{min})\end{array}$ & $\begin{array}{c}\text { Plasma conc. } \\
(\mu \mathrm{g} / \mathrm{ml})\end{array}$ & $\begin{array}{c}\text { Lowering } \\
\text { in blood } \\
\text { pressure }\end{array}$ & $\begin{array}{c}\text { Reduction } \\
\text { in heart } \\
\text { rate }\end{array}$ \\
\hline 5 & 1.16 & 9 & 0 \\
15 & 1.76 & 40 & 5 \\
30 & 2.15 & 50 & 10 \\
45 & - & 58 & 27 \\
60 & 3.40 & 66 & 45 \\
90 & 4.68 & 72 & 90 \\
120 & 5.12 & 85 & 112 \\
150 & - & 90 & 121 \\
180 & - & 91 & 125 \\
240 & 6.85 & 97 & 100 \\
300 & - & 85 & 86 \\
360 & 4.50 & 76 & 42 \\
480 & 3.75 & 35 & 10 \\
\hline
\end{tabular}

The pharmacological results obtained, clearly indicated that the administration of buccoadhesive tablet led to a significant prolongation and improvement of the antihypertensive effect compared with the oral administration of $\mathrm{VH}$ suspension. This increased bioavailability of $\mathrm{VH}$ from the buccoadhesive tablet might be due to the potential avoidance of first-pass hepatic metabolism. Considering that the absolute bioavailability of the buccal tablets is greater than the oral $\mathrm{VH}$ suspension, a lower dose of $\mathrm{VH}$ may be used in VH therapy. This could reduce the various side effects of $\mathrm{VH}$ associated with the usual higher clinical doses (Isoptin 80, 120, or $240 \mathrm{mg}$ tablets) of the drug.

\section{Conclusion}

The present investigation established the usefulness of buccoadhesive tablets as potential controlled and prolonged - release formulation of $\mathrm{VH}$. Beside the buccal administration showed a significant improvement of bioavailability of $\mathrm{VH}$ compared to that achieved by oral administration. Furthermore, the plasma concentration-time curve for buccoadhesive tablets showed evidence of sustained-release of drug $\left(\mathrm{T}_{\max }\right.$ of $4 \mathrm{~h}$ for buccoadhesive tablet compared to $2 \mathrm{~h}$ for oral administration). The buccal tablets were of satisfactory hardness and showed good bioadhesion to bovine mucosal membrane.

\section{REFERENCES}

1- C. Dollery, "Therapeutic Drugs", $2^{\text {nd }}$ ed., Churchill Livingstone, New York 2, 1999, V21-V28.

2- I. N. Findlay, K. Macleod, M. Ford, A. T. Elliot, H. J. Dargie and G. Gillen, British Heart J., 57, 336-343 (1987).

3- M. Eichelbaum and A. Somogyi, Eur. J. Pharmacol., 26, 47-53 (1984).

4- L. L. Christrup, J. Bonde, S. N. Rasmussen and M. R. Rassing, Acta. Pharm. Nord., 2, 371-376 (1990).

5- L. X. Cabeddu and N. T. Feunmayor, J. Cardiovasc. Pharmacol., 12 (Supp. 6), S188-S193 (1988).

6- A. H. Gradman, W. H. Frishman and P. M. Kaihlanen, Am. J. Cardiol., 70, 1571 (1992).

7- E. F. Reynolds, "Martindale, The Extrapharmacopeia", $\quad 30^{\text {th }} \quad$ Ed., Pharmaceutical Press, London, 1993, p. 75.

8- U. S. Pharmacopeial Convention, The United State Pharmacopeia 21/National Formulary 16, U.S. Pharmacopeial Convention. Inc.: MD. Rockville (1985).

9- J. Voorspoels, J. Remon, W. Eechaute and W. Desy, Pharm. Res., 13, 1228-1232 (1996).

10- M. A. Hussain, B. J. Aungst, C. A. Koval and E. Shefter, Pharm. Res., 5, 615-618 (1988).

11- M. A. Hussain, B. J. Aungst, A. Kearney and E. Shefter, Int. J. Pharm., 36, 127-130 (1987).

12- D. Duchene, F. Touchard and N. A. Peppas, Drug Dev. Ind. Pharm., 14 (2\&3), 283 (1988).

13- G. V. Betageri, D. V. Deshmukh and R. B. Gupta, Drug Dev. Ind. Pharm., 27 (2), 129-136 (2001).

14- P. A. M. Quiroga, G. V. Yuln, M. Palummo, A. Cingolani, L. L. Dall and M. G. Volonte, Drug Dev. Ind. Pharm., 27 (10), 1099-1106 (2001). 
15- G. A. El-Gindy, A. M. El-Sayed, A. M. Abdel-Magied and Gh. M. Abdel-Aal, Bull. Pharm. Sci., Assiut Univ., 25 (2), 125-135 (2002).

16- D. Belül, O. Leyla and U. Nurseli, Drug. Dev. Ind. Pharm., 24 (3), 281-288 (1998).

17- E. Watson and P. A. Kapur, J. Pharm. Sci., 70, 800-801 (1981).

18- A. C. Jain, B. J. Aungst and M. C. Adeyeye, J. Pharm. Sci., 91 (7), 16591668 (2002).

19- Y. W. Chien, S. E. Kenneth and S. Chang, "Drugs and the Pharmaceutical Sciences: NaSal Systemic Drug Delivery", Vol. 39, Marcel Dekker, Inc. New York, 1989, pp. 27-37.

20- B. G. Katzung, "Basic and Clinical Pharmacology", $6^{\text {th }}$ ed., Appelton and Lange, Middle East Edition, 1995, pp. 205-229.

21- P. Bottenberg, R. Cleymaet, C. De. Muynck, J. P. Remon, D. Coomans, Y. Michotte and D. Slope, J. Pharm. Pharmacol., 43, 457-464 (1991).

22- T. C. Dahi, T. Calderwood, A. Bormeths and K. Trimble, J. Controlled Release, 14, 1 (1990).
23- N. Garcia-Gonzalez, I. Kellaway, H. Blanco-Fuente, S. Anguiano-Igea, B. Delgado-Charro, F. Otero-Espinar and J. Blanco-Mendez, Int. J. Pharm., 100, 65-70 (1993).

24- H. G. Choi, M. H. Kim, M. K. Lee and C. K. Kim, Int. J. Pharm., 190, 13-19 (1999).

25- C. K. Kim, S. W. Lee, H. G. Choi, M. K. Lee, Z. G. Gao and J. S. Kim, Int. J. Pharm., 174, 201-207 (1998).

26- M. O. Yun, H. G. Choi, J. H. Jung and C. K. Kim, Int. J. Pharm., 189, 137-145 (1999).

27- B. Dortunc, L. Özer and N. Uyanik, Drug. Dev. Ind. Pharm., 24 (3), 281-288 (1998).

28- A. K. Singla, M. Chawla and A. Singh, Drug Dev. Ind. Pharm., 26, 9, 913-924 (2000).

29- N. A. Peppas and J. J. Sahlin, Int. J. Pharm., 57, 169-172 (1989).

30- M. Gibaldi and D. Perrier, "Drugs and The Pharmaceutical Sciences: Pharmacokinetic", $\left(2^{\text {nd }}\right.$ ed.). Marcel Dekker, Inc., New York and Basel, 1982, pp. 221-267. 